\title{
Transformer Less Grid Integrated Single Phase PV Inverter Using Prognosticative Control
}

\author{
Chandla Ellis $^{1, *}$, C. Chellamuthu ${ }^{1}$ and J. Jayaseelan ${ }^{2}$ \\ ${ }^{1}$ Department of Electrical and Electronics Engineering, R.M.K Engineering College, Chennai, 601206, Tamil Nadu, India \\ ${ }^{2}$ Department of Mechanical Engineering, Dr. M G R Educational and Research Institute, Chennai, 601206, Tamil Nadu, India \\ *Corresponding Author: Chandla Ellis. Email: chandalaellis234@gmail.com \\ Received: 27 August 2021; Accepted: 22 October 2021
}

\begin{abstract}
Nature's remarkable and merciful gift to the planet Earth is sunlight which may be highly lucrative if harvested and harnessed properly. Photovoltaic $(\mathrm{PV})$ panels are used to convert the solar energy to electrical energy which are currently used to feed AC loads/grid. In this paper, modelling, performance and power flow studies of grid connected single phase inverter fed from PV array under steady state as well as transient conditions are considered. This paper focuses on the study and development of analytical model of micro-grid integrated single phase five level cascaded H-bridge inverter (MGISPFLCHBPVI) powered by a PV panel. A simple power control strategy for MGISPFLCHBPVI is also considered. The simulations are completely carried out using MATLAB software for power-flow studies. The performance characteristics of the inverter are studied from the analytical model developed. The validation of the analytical model is carried out by comparing the results of simulation in Simulink/Matlab. In order to reduce the time to reach steady state taken by the system, a simple PQ control strategy for insolation is introduced in this paper. The proposed method is evaluated based on performance parameters such as settling time and rising time of the system compared with the results available in the literature.
\end{abstract}

Keywords: AC loads/grid; PV array; PV panels; single phase inverter; switches; P-Q control; insolation

\section{Introduction}

Sunlight is readily available in abundance all over the world and its proper deployment eliminates approximately $45 \%$ power deficiency existing globally. Extracting maximum power from PV array increases the overall efficiency of the PV system [1]. In order to extract maximum energy available from PV array, power electronic converters are designed and utilized with solar arrays and load thus the system serves as a stand-alone PV system [2]. Solar cells are the basic unit of PV generator, which are connected in series to build a PV module. PV strings are built by connecting solar modules in series. The PV strings are connected together in series and parallel to build a PV array to meet the voltage and power requirements [3].

This work is licensed under a Creative Commons Attribution 4.0 International License, which permits unrestricted use, distribution, and reproduction in any medium, provided the original work is properly cited. 
The energy yield study of $1 \mathrm{kWp}$ residential PV plant at Chennai is considered for brief discussion. The diurnal, monthly and seasonal variation of solar radiation at Chennai during the years 2013, 2014 and 2015 are recorded. Similarly, the output energy yield of the PV plant during the year 2013, 2014 and 2015 are also estimated and recorded [4]. The research based on the I-V and P-V performance characteristics of PV system for varying environmental conditions is considered in [5]. Solar array is designed and its system performances are validated under varying environmental and load conditions [6]. Different models of panel such as four and five parameters are briefly discussed and it is inferred that the performance of five parameter model matches closely with the manufacturers data as discussed in [7-9]. A PV panel cannot be directly integrated to unipolar/bipolar dc bus and it requires a suitable dc-dc converter as explained in [10]. The single phase inverter is required in order to transport power from PV array to AC micro-grid. Different switching pulse generation methods and configurations for single phase grid connected inverter are studied and compared as presented in [11]. Further, it is mentioned that the system takes much time to reach steady state values. Different power control techniques involving closed loop methods for grid integrated PV inverter are briefly discussed in [12-16].

Based on the review, a modified five parameter analytical model of PV array is developed and its performance is obtained for different operating conditions. This paper focuses on the study and development of analytical model of micro-grid integrated single phase five level cascaded H-bridge inverter (MGISPFLCHBPVI) powered by a PV panel as shown in Fig. 1. A simple power control strategy for MGISPFLCHBPVI is also considered. The simulations are completely carried out using MATLAB software for power-flow studies.

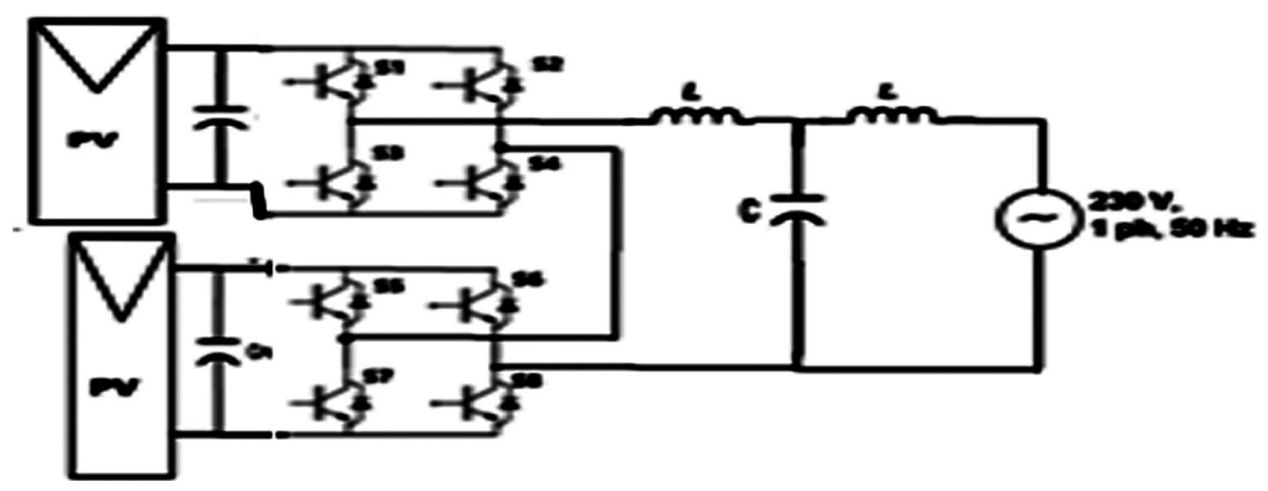

Figure 1: Circuit model of MGISPFLCHBPVI

\section{Photovoltaic Array}

The equivalent electrical circuit model of a silicon photovoltaic cell consists of a controlled dc current source $\left(I_{L}\right)$, a PN junction diode $D$, a shunt resistance $R_{s h}$ connected in parallel and a series resistance $R_{s e}$ as shown in Fig. 2.

The mathematical expression used to calculate the output current of solar cell is given by Eq. (1).

$I_{P V}=I_{L}-I_{0}\left(e^{\frac{V_{P V}+I_{P V} R_{s e}}{N V_{T}}}-1\right)-\frac{V_{P V}+I_{P V} R_{s e}}{R_{s h}}-C \frac{d V_{P V}}{d t}$

where $\mathrm{I}_{\mathrm{L}}$ is the measured photocurrent for the irradiance $\mathrm{S}\left(\mathrm{W} / \mathrm{m}^{2}\right), \mathrm{I}_{0}$ is the diode reverse saturation current, $\mathrm{V}_{\mathrm{T}}$ is diode thermal voltage and $\mathrm{V}_{\mathrm{T}}=\mathrm{k}_{\mathrm{b}} * \mathrm{~T}_{\text {cell }} / \mathrm{q}, \mathrm{k}_{\mathrm{b}}$ is Boltzmann constant and $\mathrm{k}_{\mathrm{b}}=1.3807 \times 10^{-23} \mathrm{~J} \mathrm{~K}^{-1}$, $\mathrm{q}$ is charge of a proton where $\mathrm{q}=1.602 \times 10^{-19} \mathrm{C}, \mathrm{T}_{\text {cell }}$ is working temperature of PV cell, $\mathrm{V}_{\mathrm{PV}}$ is the output voltage across the solar cell, $I_{P V}$ is the output current of the cell, $R_{s e}$ and $R_{s h}$ are series and shunt resistances, $\mathrm{N}$ is diode ideality factor. The ideality factor varies for amorphous cells, and is typically 
1-2 for polycrystalline cells and less than 1 for mono-crystalline silicon cells (c-Si). The expression used to calculate the reference and generated photo current are given by Eqs. (2) and (3) respectively.

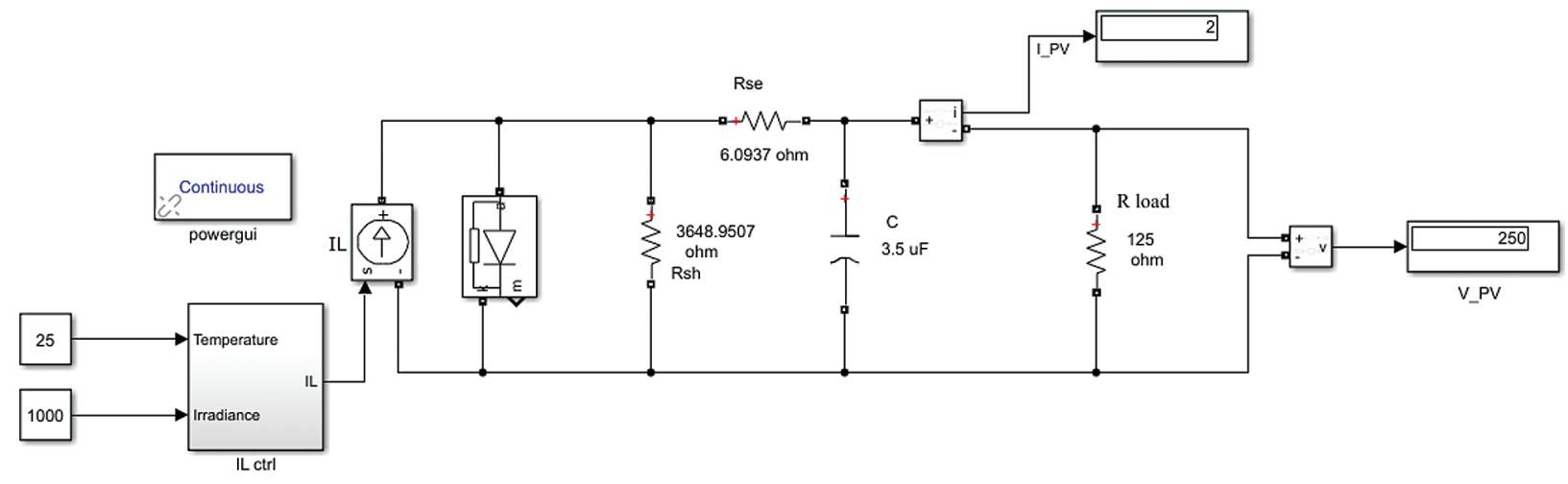

Figure 2: Single diode model of a solar cell

$I_{\text {Lref }}=I_{\text {scref }}\left(\frac{R_{s h}+R_{s e}}{R_{s h}}\right)$

$I_{L}=\frac{S}{S_{\text {ref }}}\left\{I_{\text {Lref }}+\alpha_{\text {isc }}\left(T_{\text {cell }}-T_{\text {ref }}\right)\right\}$

where $I_{L}$ is the photo-current generated, $S_{\text {ref }}$ is standard insolation $\left(1000 \mathrm{~W} / \mathrm{m}^{2}\right), I_{\text {scref }}$ is short circuit of PV array at STC, $\alpha_{\text {isc }}$ is temperature coefficient of current $\left(0.102 \%{ }^{\circ} \mathrm{C}^{-1}\right), \mathrm{T}_{\text {cell }}$ and $\mathrm{T}_{\text {ref }}\left(298 \mathrm{~K}\right.$ or $\left.25^{\circ} \mathrm{C}\right)$ are cell and reference temperatures in kelvin.

The expression used to calculate the energy band gap can be written as

$E_{g}=E_{\text {gref }}\left\{1+d E_{g} d T\left(T_{\text {cell }}-T_{\text {ref }}\right)\right\}$

where $\mathrm{dE}_{\mathrm{g}} \mathrm{dT}$ is energy band gap coefficient and $\mathrm{dE}_{\mathrm{g}} \mathrm{dT}=-0.02677 \%\left(\mathrm{eV}^{\circ} \mathrm{C}^{-1}\right), \mathrm{E}_{\text {gref }}$ is reference energy band gap of Si diode and it is equal to $1.12 \mathrm{eV}$.

The diode quality factor and PV array shunt resistance can be mathematically estimated using Eqs. (5) and (6) respectively.

$N=\left\{\frac{\left(V_{M P P}-I_{M P P} R_{s e}\right)\left(V_{M P P}-\left(I_{s c}-I_{M P P}\right) R_{s h}^{(0)}\right)}{\left(V_{M P P}-I_{M P P} R_{s h}^{(0)}\right) V_{T}} \approx 1 n_{c} \times N_{s e} ; 1<n_{c}<1.5\right.$

$R_{s h}=\frac{\left(V_{M P P}-I_{M P P} R_{s e}\right)\left(V_{M P P}-\left(I_{s c}-I_{M P P}\right) R_{s e}-N V_{T}\right)}{\left(V_{M P P}-I_{M P P} R_{s e}\right)\left(I_{s c}-I_{M P P}\right)-N V_{T} I_{M P P}}$

where $\mathrm{V}_{\mathrm{MPP}}$ and $\mathrm{I}_{\mathrm{MPP}}$ are peak voltage and peak current of PV array, $\mathrm{R}_{\mathrm{sh}}{ }^{(0)}$ is shunt resistance at short circuit condition which can be estimated using Eq. (7).

$R_{s h}^{(0)}=\left.\frac{\partial V_{p v}}{\partial I_{p v}}\right|_{I_{p v}=I_{s c}}$ 
The mathematical expression used to calculate the reference thermal voltage, array thermal voltage, reference diode reverse saturation current and diode reverse saturation current are given in Eqs. (8)-(11) respectively.

$V_{\text {Tref }}=\frac{N_{\text {cells }} k_{b} T_{\text {ref }}}{q}$

$V_{T}=V_{\text {Tref }}\left(\frac{T_{\text {cell }}}{T_{r e f}}\right)$

$I_{0 r e f}=\frac{I_{s c_{r e f}}}{e^{\left(\frac{q V_{o c} r e f}{N_{k} T_{r e f}}\right)}-1}$

$I_{0}=I_{0 \text { ref }}\left\{\left(\frac{T_{\text {cell }}}{T_{\text {ref }}}\right)^{(3 / N)} e^{\left(\left(\frac{q E_{\text {gref }}}{N k_{b} T_{\text {ref }}}\right)-\left(\frac{q E_{g}}{N k_{b} T_{\text {cell }}}\right)\right)}\right\}$

where $\mathrm{I}_{\text {scref }}$ and $\mathrm{V}_{\text {ocref }}$ are short circuit current and open circuit voltage of PV array at standard test conditions $\left(1 \mathrm{~kW} / \mathrm{m}^{2}\right.$ at $\left.25^{\circ} \mathrm{C}\right)$. Based on Eqs. (1) to (11), the five-parameter mathematical model to calculate PV output current is developed as shown in Fig. 3.

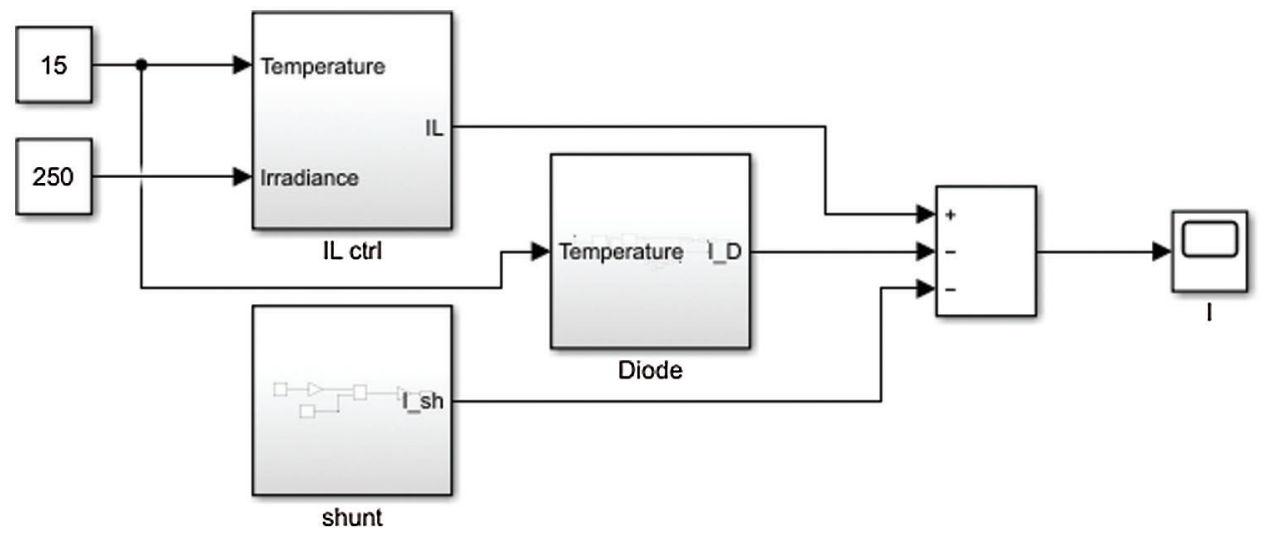

Figure 3: Five-Parameter mathematical model of PV current generator

\subsection{Study of Residential PV Plant}

The design and analysis of a $1 \mathrm{kWp}, 250 \mathrm{~V}$ domestic roof-top PV panel situated at Chennai is considered for performance study. The specification of stand-alone PV panel is shown in Tab. 1.

Table 1: Specifications of stand-alone PV panel

\begin{tabular}{ll}
\hline Parameters & Values \\
\hline PV cell area & $8.2 \mathrm{~cm} \times 8.2 \mathrm{~cm}$ \\
No. of series connected cells in a PV string & 500 \\
No. of parallel connected strings in PV array & 2 \\
\hline &
\end{tabular}




\begin{tabular}{ll}
\hline Table 1 (continued). & \\
\hline Parameters & Values \\
\hline Open circuit voltage at STC & $300 \mathrm{~V}$ \\
Short circuit current at STC & $4.34 \mathrm{~A}$ \\
Maximum power(MP) at STC & $1 \mathrm{~kW}$ \\
Voltage at maximum power point(STC) & $250 \mathrm{~V}$ \\
Current at maximum power point(STC) & $4 \mathrm{~A}$ \\
Coupling capacitor & $3.5 \mu \mathrm{F}$ \\
Load Resistance at MPP(STC) & $62.5 \Omega$ \\
\hline
\end{tabular}

\subsection{Simulink Model of PV System}

The Simulink model of stand-alone $1 \mathrm{~kW}, 250 \mathrm{~V}$ PV panel is developed as shown in Fig. 4.

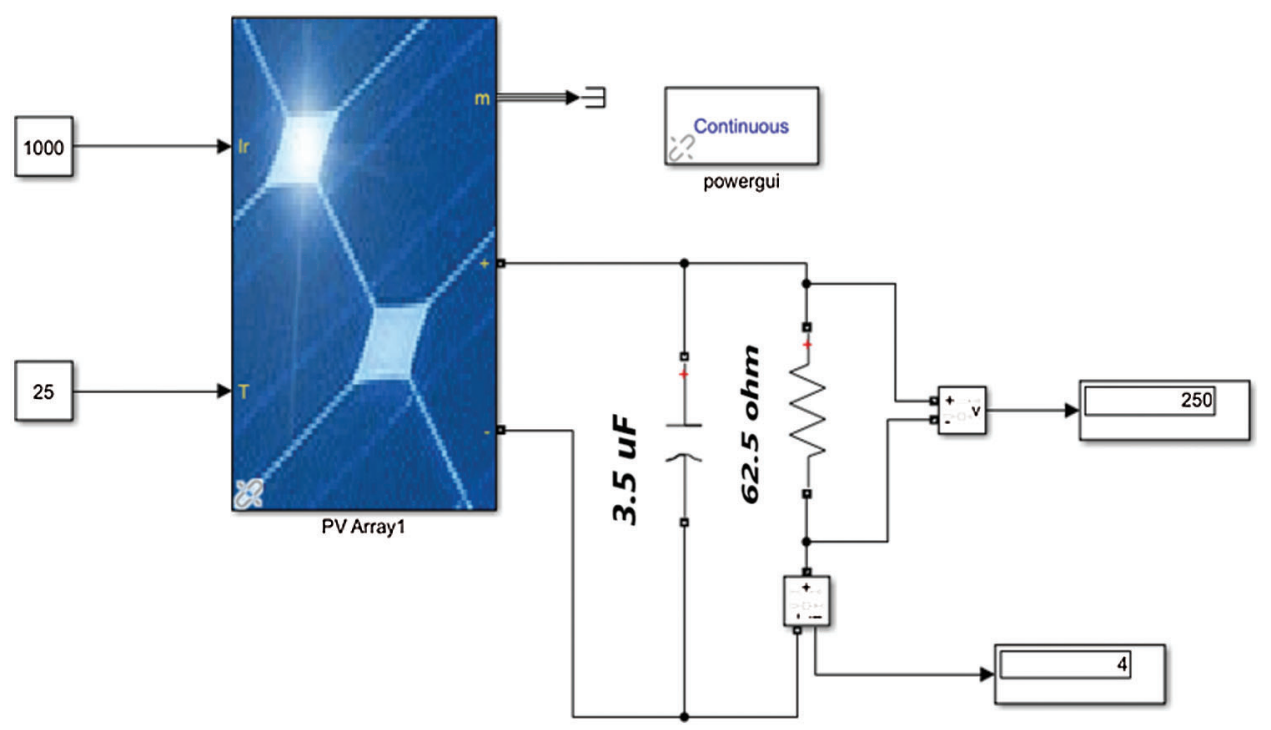

Figure 4: Simulink diagram of stand-alone PV system connected to a resistive load

In a typical scenario both temperature and insolation may vary during an operation. The typical variations of insolation and temperature are depicted in the Figs. 5 and 6 respectively.

The simulation is run for $6 \mathrm{~ms}$ with above data as inputs. The performance of the output voltage for $\mathrm{R}$ and RL load are recorded as shown in the Fig. 7.

For step increase in insolation from 850 to $1000 \mathrm{~W} / \mathrm{m}^{2}$, the output voltage rises exponentially from $222.8 \mathrm{~V}$ and settles at $250 \mathrm{~V}$ in $0.5 \mathrm{~ms}$. For step increase in temperature from 25 to $40^{\circ} \mathrm{C}$, the load voltage exponentially decays from $250 \mathrm{~V}$ and settles to $241.3 \mathrm{~V}$ in $0.3 \mathrm{~ms}$ with an undershoot of about $1 \mathrm{~V}$. The response is in line with the reports published already. 


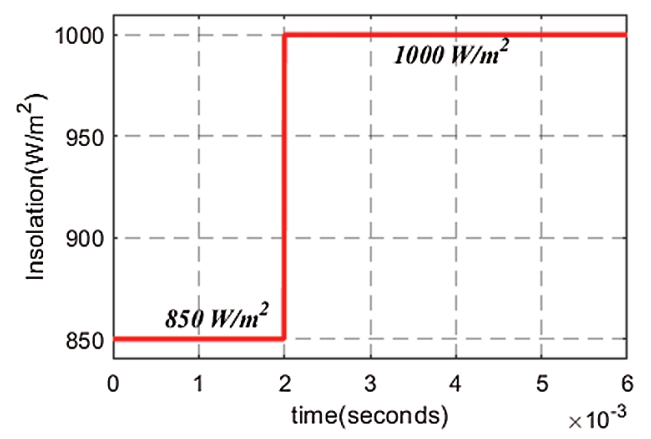

Figure 5: Step change in insolation from 850 to $1000 \mathrm{~W} / \mathrm{m}^{2}$ at $2 \mathrm{~ms}$

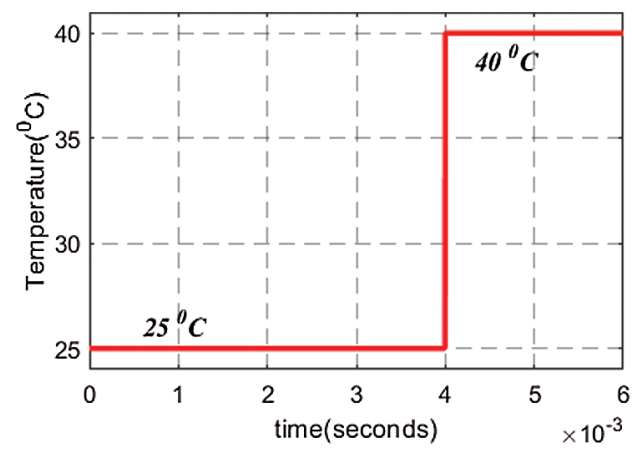

Figure 6: Step change in temperature from $25^{\circ} \mathrm{C}$ to $40^{\circ} \mathrm{C}$ at $4 \mathrm{~ms}$

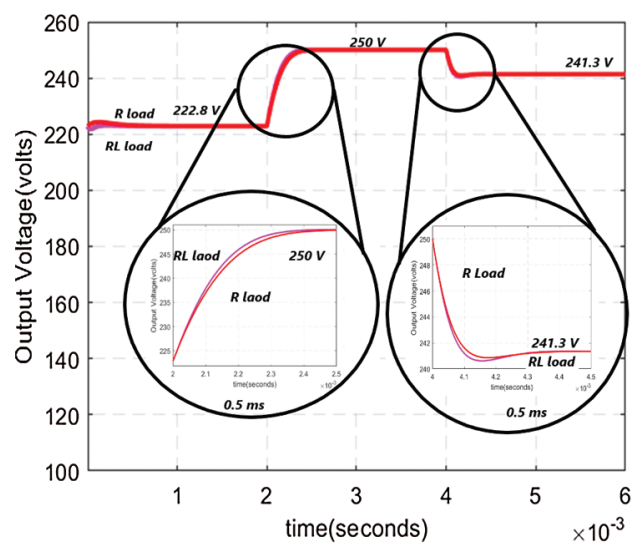

Figure 7: Load voltage response for temperature and insolation variation

\section{Single Phase Five Level Cascaded H-Bridge Inverter}

The power circuit of a $1 \mathrm{~kW}, 230 \mathrm{~V}, 5.4$ A single phase five level cascaded H-bridge inverter (SPFLCHBI) consists of a pair of DC voltage source $\left(V_{D C}\right)$, two cascaded H-bridge inverters with eight switches, low pass filter and a load as shown in Fig. 8. 


\begin{tabular}{|c|c|}
\hline Load & $\mathbf{x}$ (deg) \\
\hline UPF & Zero \\
\hline $\begin{array}{c}0.8 \mathrm{pf} \\
\text { lag }\end{array}$ & -36.86 \\
\hline $\begin{array}{c}0.8 \mathrm{pf} \\
\text { lead }\end{array}$ & +36.86 \\
\hline
\end{tabular}

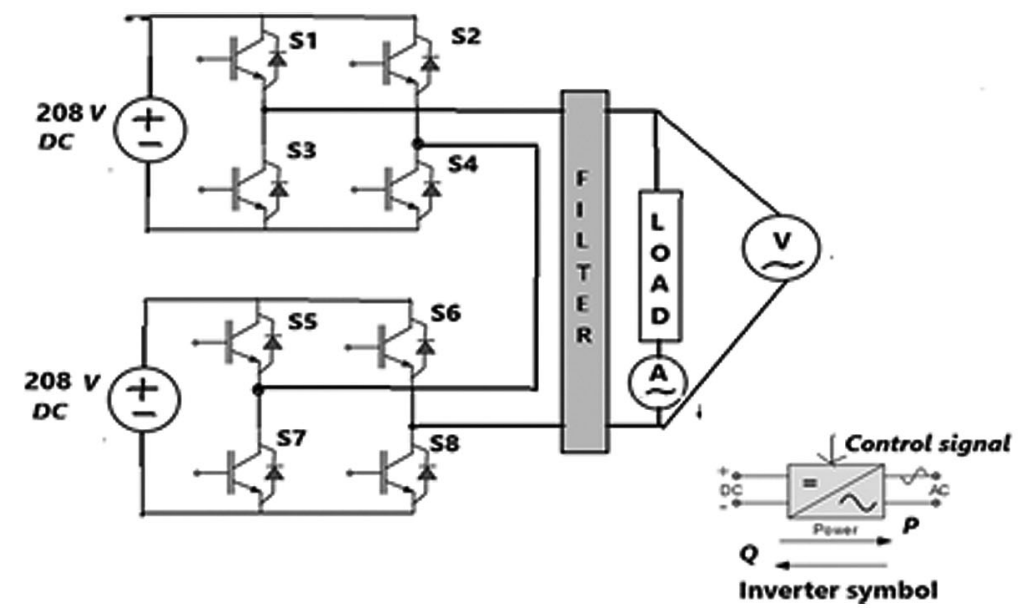

Figure 8: Schematic diagram of SPFLCHBI feeding a load

A pair of $208 \mathrm{~V}$ DC is considered as input voltage for SPFLCHBI. The frequency operation of inverter ranges from 49.5 to $50.5 \mathrm{~Hz}$ with nominal frequency of $50 \mathrm{~Hz}$. The modulation index ranges from 0.7 to 0.9 with nominal value of 0.8. A $300 \mathrm{~V}$ NPN MOSFET is considered for power switch. An LC filter with a cut off frequency of $1.5 \mathrm{kHz}$ is considered for filter operation so that voltage is sinusoidal at the point of coupling to the grid. The filter inductance and filter capacitance are specified as $4 \mathrm{mH}$ and $3 \mu \mathrm{F}$ respectively. The $1 \mathrm{~kW}, 230 \mathrm{~V}$ resistive loads is realized using a $53 \Omega$ wire wound resistor. In order to realize $1 \mathrm{~kW}, 230 \mathrm{~V}$ inductive load of $0.8 \mathrm{pf}$, a resistance of $42.32 \mathrm{ohm}$ is connected in series with a $0.1013 \mathrm{H}$ inductor, rated 8 amperes. A $100 \mu \mathrm{F}, 400 \mathrm{~V} \mathrm{AC}$ capacitor is connected with $42.32 \mathrm{ohm}$ in order to realize a $1 \mathrm{~kW}, 230 \mathrm{~V} 0.8 \mathrm{pf}$ capacitive load. The positive and negative half-cycle switching pattern for SPFLCHBI is shown in Tab. 2. The triggering pulse generation using in phase disposition method is shown in Fig. 9.

Table 2: Switching sequence of SPFLCHBI for positive and negative half cycles

\begin{tabular}{lllllllll}
\hline Switch number/voltage & $\mathrm{S}_{1}$ & $\mathrm{~S}_{2}$ & $\mathrm{~S}_{3}$ & $\mathrm{~S}_{4}$ & $\mathrm{~S}_{5}$ & $\mathrm{~S}_{6}$ & $\mathrm{~S}_{7}$ & $\mathrm{~S}_{8}$ \\
\hline$+\mathrm{V}_{\mathrm{DC}} / 2$ & 1 & 0 & 0 & 1 & 1 & 1 & 0 & 0 \\
$-\mathrm{V}_{\mathrm{DC}} / 2$ & 0 & 1 & 1 & 0 & 0 & 0 & 1 & 1 \\
0 & 0 & 0 & 0 & 0 & 0 & 0 & 0 & 0 \\
$+\mathrm{V}_{\mathrm{DC}}$ & 1 & 0 & 0 & 1 & 1 & 0 & 0 & 1 \\
$-\mathrm{V}_{\mathrm{DC}}$ & 0 & 1 & 1 & 0 & 0 & 1 & 1 & 0 \\
\hline
\end{tabular}

The carrier signal and modulating signal frequencies are set as $10 \mathrm{kHz}$ and $50 \mathrm{~Hz}$ respectively. The modulating and carrier signals waveforms for SPWM is shown in Fig. 10. The switching pulse waveforms for upper and lower bridge switches during one cycle are shown in Figs. 11 and 12 respectively.

The Modulation Index (MI) can be calculated using the expression given in Eq. (12)

Modulation Index $=\frac{2 B_{m}}{(n-1) B_{c}}$

where $B_{m}$ is the amplitude of sinusoidal modulating signal, $B_{c}$ is the amplitude of triangular carrier signal and $n$ represents the number of CHBI levels. 


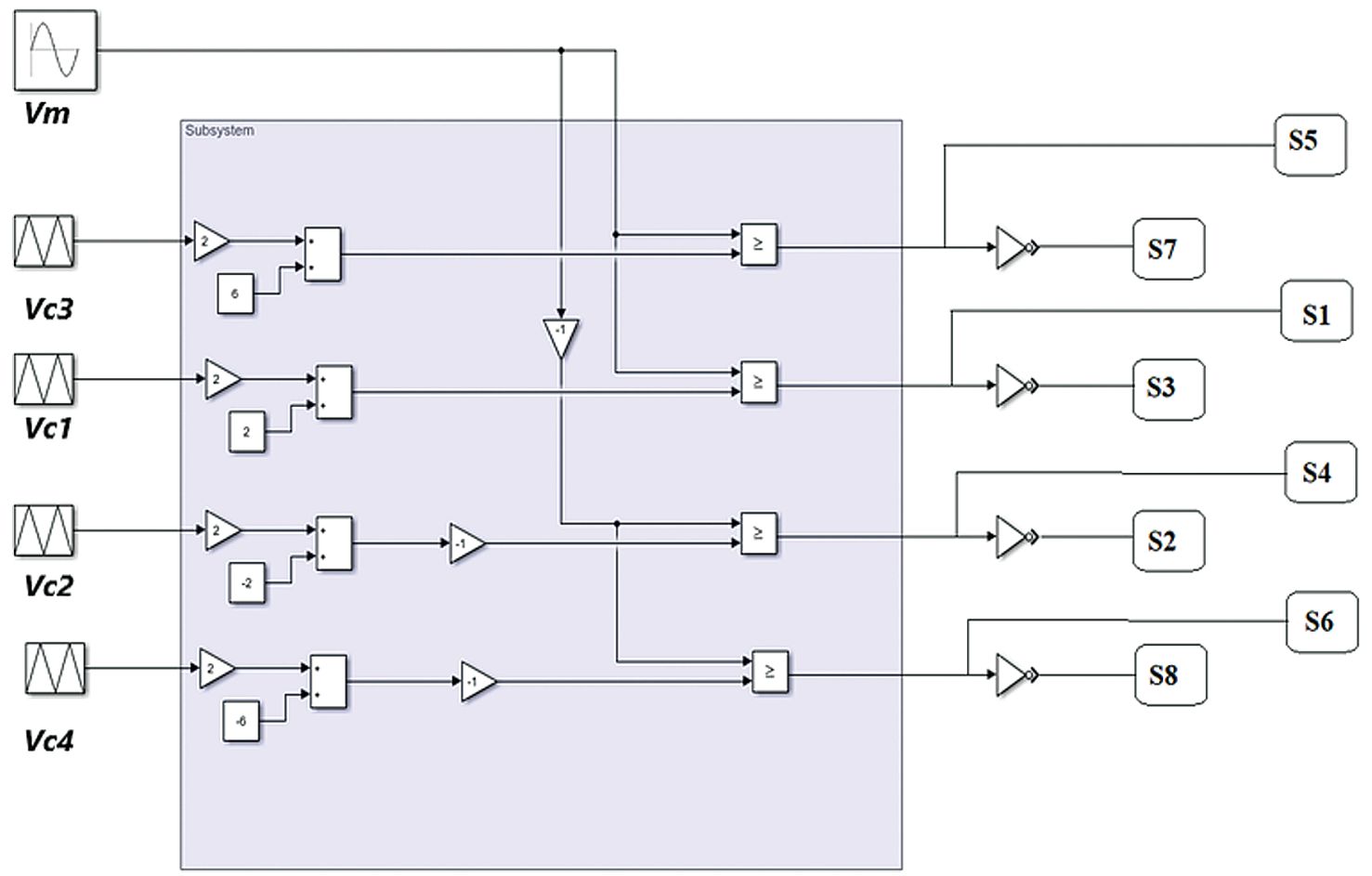

Figure 9: Circuit for gate pulse generation

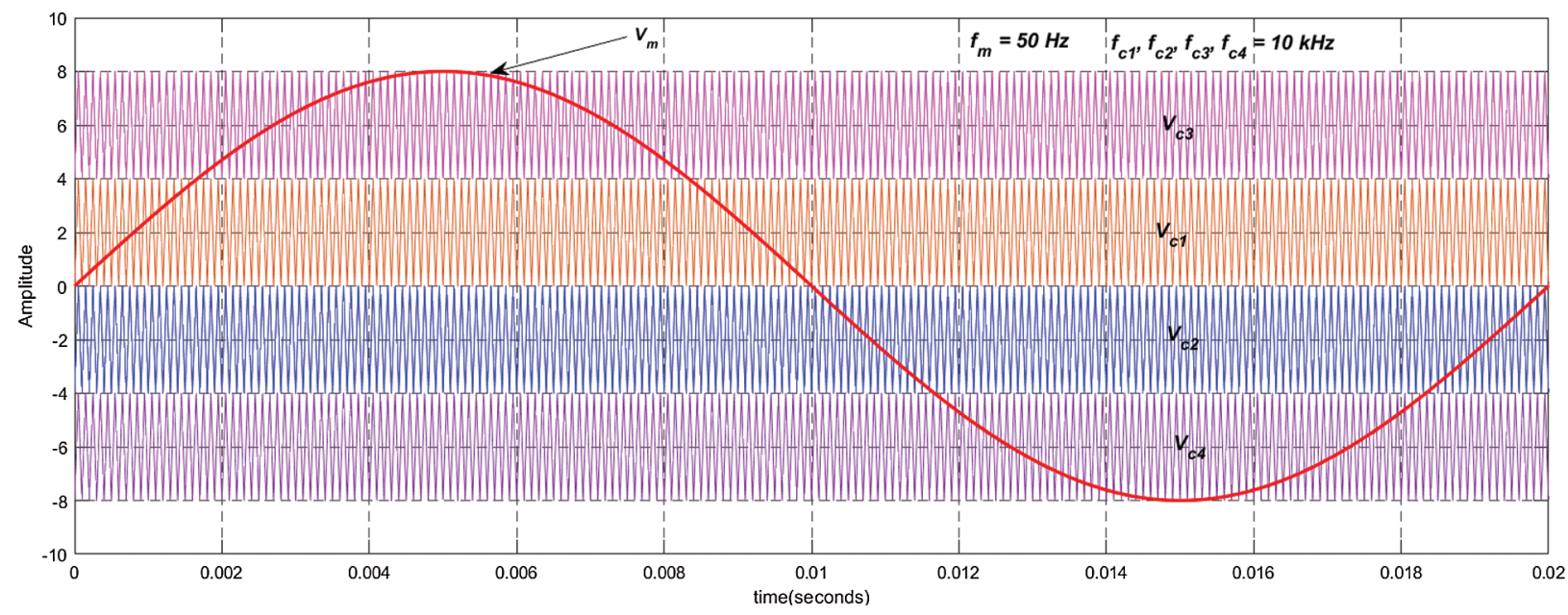

Figure 10: Waveforms of modulating and carrier signals for SPWM

The RMS voltage for different values of modulation index (MI) under various power factor conditions are calculated and plotted as shown in Fig. 13. For a given MI range 0.7-0.9, $V_{R C}>V_{R}>V_{R L}$ and the variation of RMS voltage with respect to MI is found to be linear. For MI 0.786, the voltage regulation characteristics for different power factors are plotted as shown in Fig. 14. The no-load voltage is set to $231 \mathrm{~V}$. It is observed that when the inverter gets loaded, $V_{R}$ and $V_{R L}$ droops linearly whereas $V_{R C}$ rises almost linear. The voltage regulation of the inverter feeding lagging, leading and unity power factor loads are computed as $+4.35 \%,-1.37 \%$ and $+2.1 \%$ respectively. 


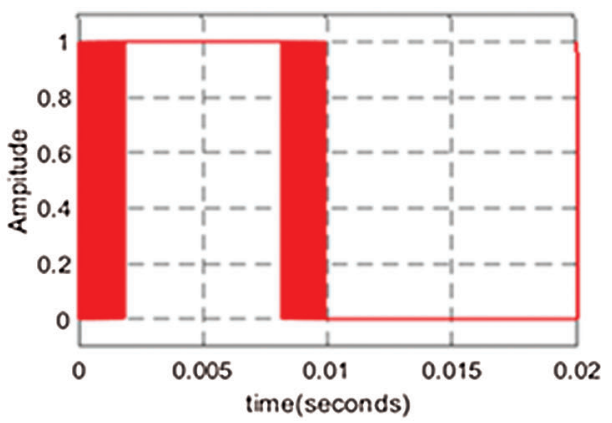

(a)

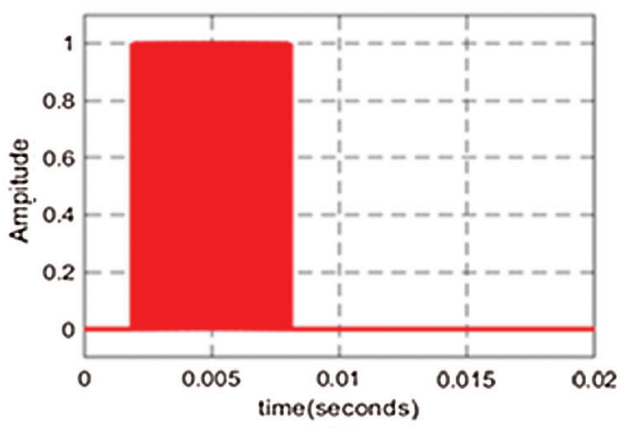

(c)

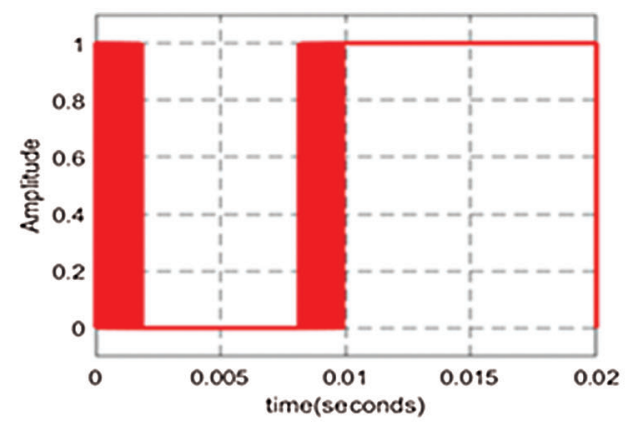

(b)

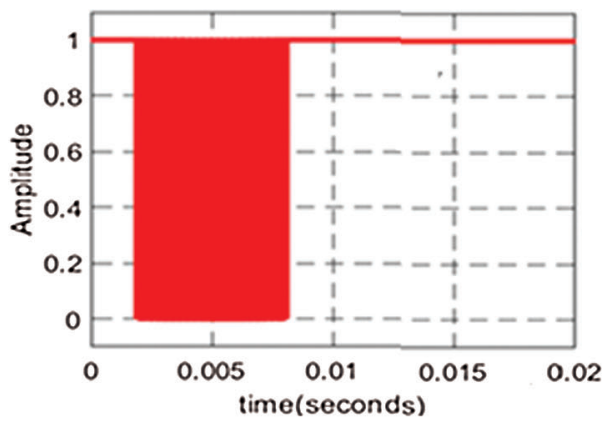

(d)

Figure 11: Gate pulse waveforms of upper bridge switches during a cycle. (a) Switch S1 (b) Switch S3 (c) Switch S5 (d) Switch S7

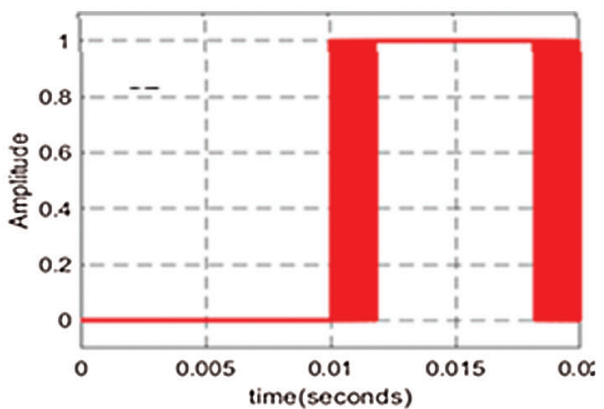

(a)

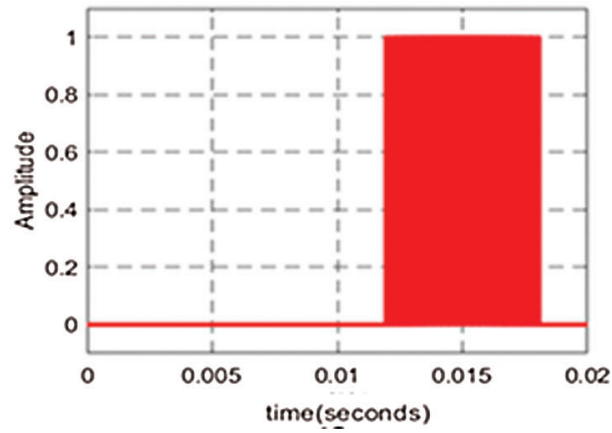

(c)

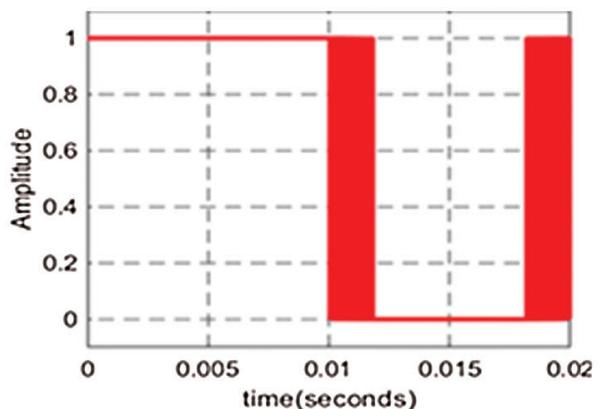

(b)

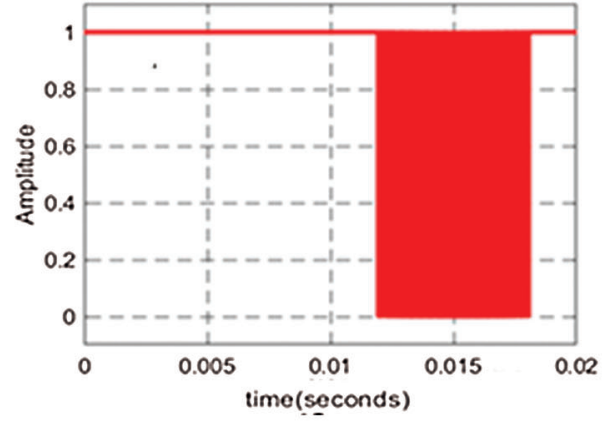

(d)

Figure 12: Gate pulse waveforms of lower bridge switches during a cycle. (a) Switch S2 (b) Switch S4 (c) Switch S6 (d) Switch S8 


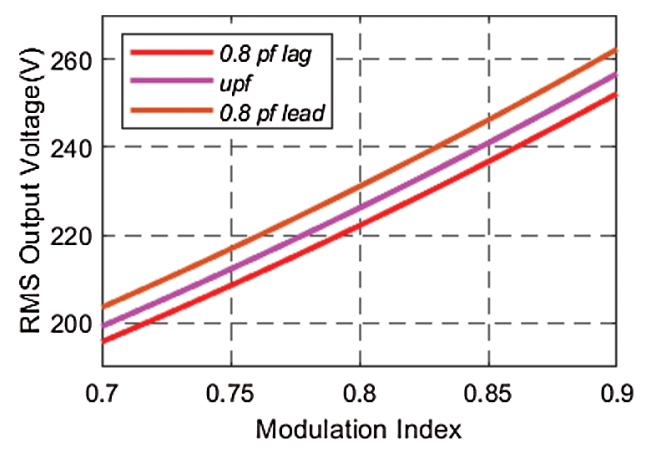

Figure 13: Steady state RMS output voltage vs. MI for different loads

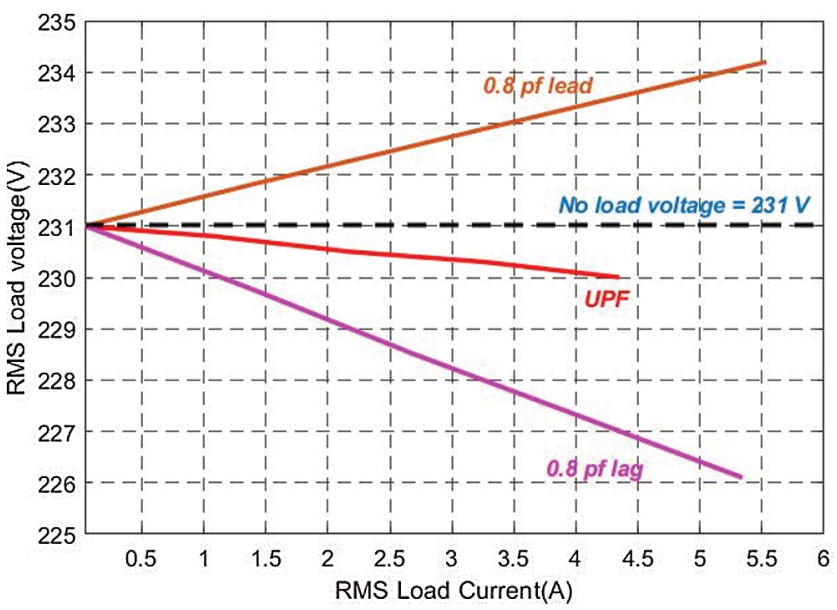

Figure 14: Regulation characteristics of SPFLCHBI feeding different loads

The Simulink model of $1 \mathrm{kWp}$ stand-alone single phase inverter fed from PV array is developed as shown in Fig. 15. The load resistance is set to $160 \Omega$ to realize $1 \mathrm{~kW}$ output. In order to study transient voltage performance of the system, the typical variation in insolation and temperature are considered as shown in Fig. 16. The simulation is run for $80 \mathrm{~ms}$ and PV voltage, inverter voltage and inverter current are shown in Figs. 17-19 respectively.

For step decrease in insolation from 1000 to $800 \mathrm{~W} / \mathrm{m}^{2}$ at $0.04 \mathrm{~s}$, the peak voltage decreases from 565.6 $\mathrm{V}$ and settles at $553.5 \mathrm{~V}$. The output current peak decreases from 3.535 to $3.46 \mathrm{~A}$. For step increase in temperature from $25^{\circ} \mathrm{C}$ to $45^{\circ} \mathrm{C}$ at $0.06 \mathrm{~s}$, the peak voltage decreases from $553.5 \mathrm{~V}$ and settles at $520 \mathrm{~V}$. Similarly, the output current peak decreases from 3.46 to 3.21 A. It is seen from the results that there are no noticeable transients in the voltage and current wave forms. 


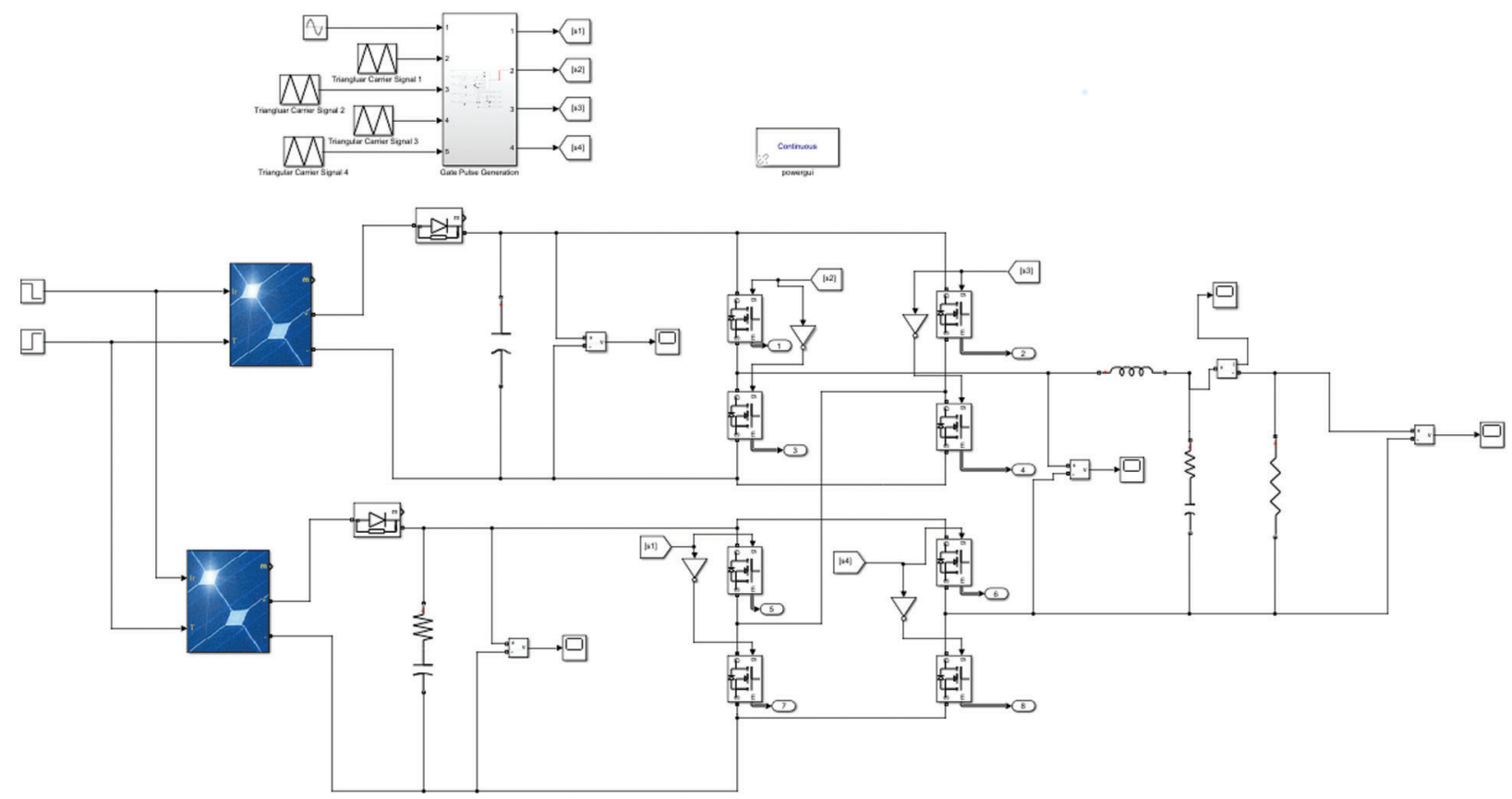

Figure 15: Simulink model of stand-alone single phase inverter fed from PV array

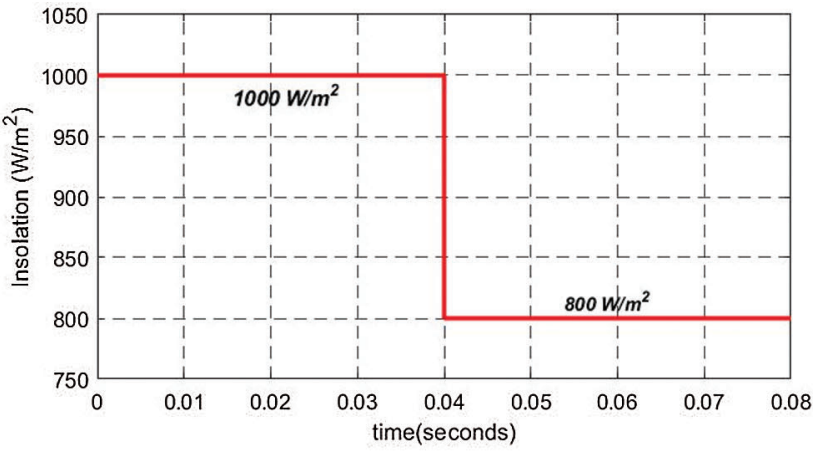

(a)

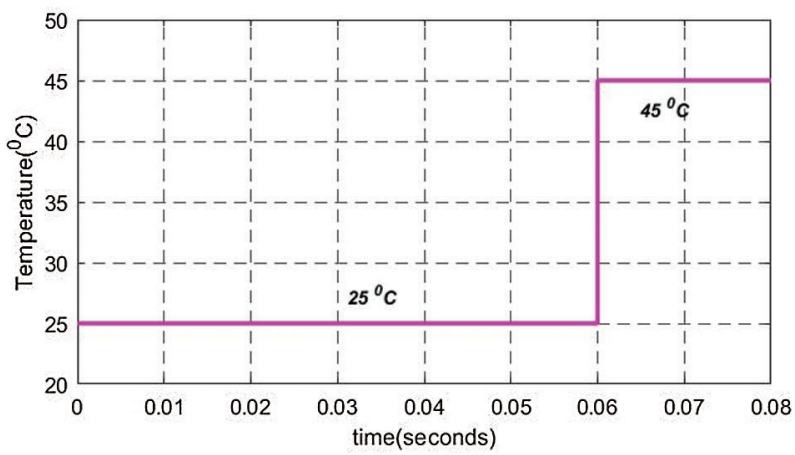

(b)

Figure 16: Insolation and temperature variation. (a) Insolation variation (b) Temperature variation

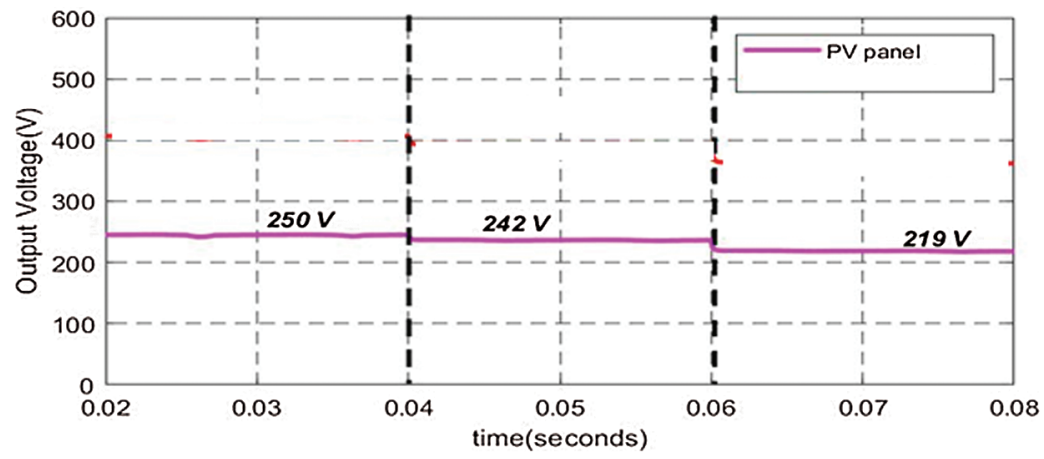

Figure 17: Output voltage response of PV panels 


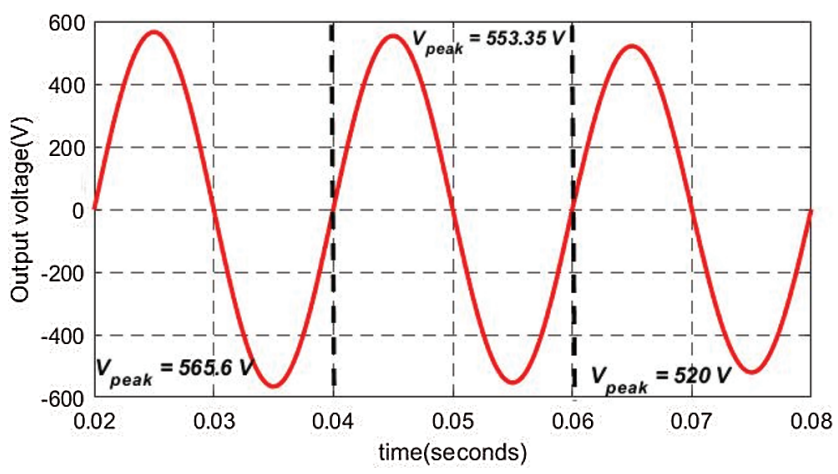

Figure 18: Output voltage waveform

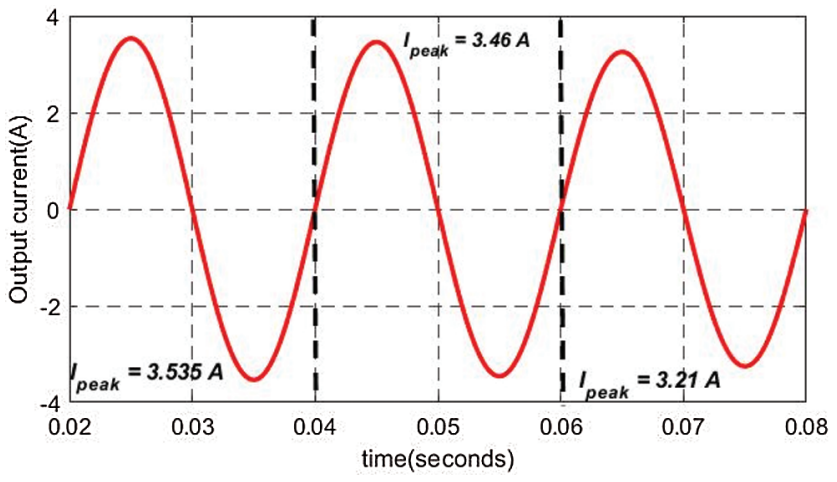

Figure 19: Output current waveform

\section{Grid Integrated Single Phase Inverter Fed from PV Panels}

The analytical model of MGISPFLCHBPVI is developed using MATLAB function as shown in Fig. 20. While integrating the single phase PV inverter system with the grid, the maximum power transmission control is established by implementing a feed forward control strategy such that it eliminates the requirement conventional feedback systems. The modified maximum power point tracking (MPPT) technique is briefly discussed in Section 5.2.

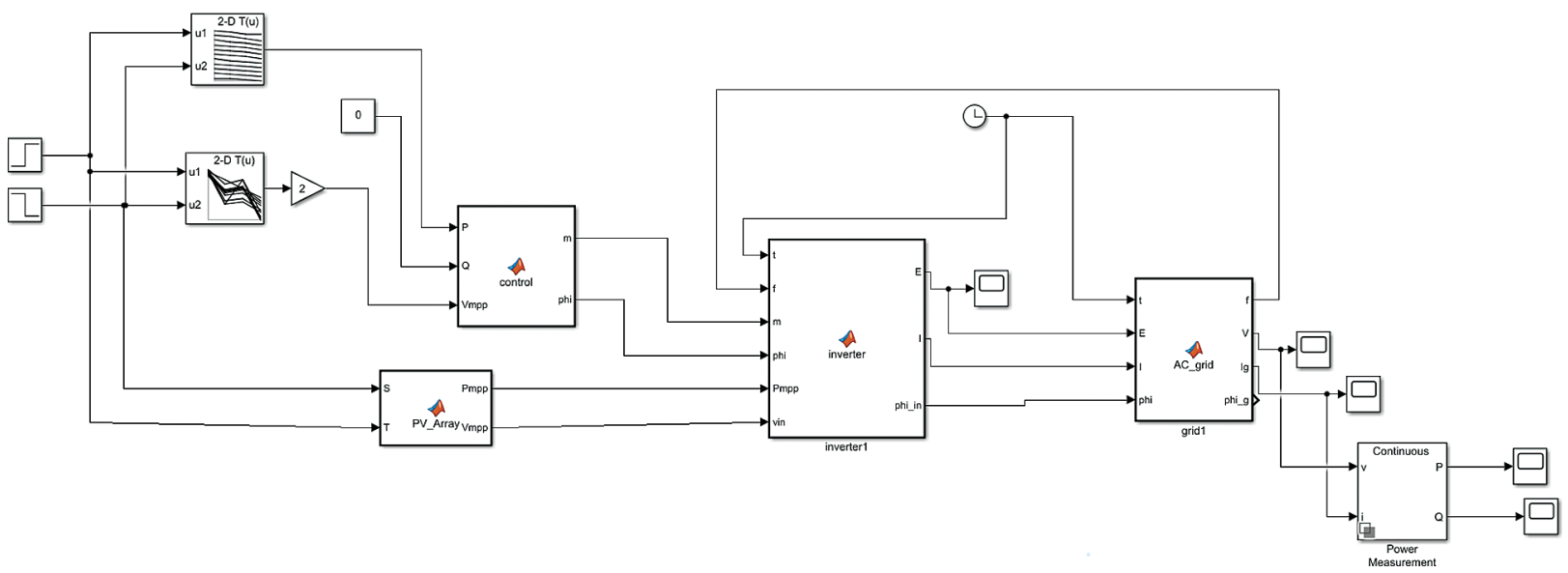

Figure 20: Analytical model of MGISPFLCHBPVI 
Based on I-V and P-V characteristics of $1 \mathrm{kWp}, 250 \mathrm{~V}$ PV array, a 2-D lookup table model for extracting maximum power from PV array is constructed using MATLAB/Simulink platform. Two lookup tables are constructed for estimating $\mathrm{V}_{\mathrm{MPP}}$ and $\mathrm{P}_{\mathrm{MPP}}$ with each table having inputs as solar insolation $\left(\mathrm{W} / \mathrm{m}^{2}\right)$ and cell temperature $\left({ }^{\circ} \mathrm{C}\right)$.

The real power $\left(\mathrm{P}_{\mathrm{g}}\right)$ and reactive power $\left(\mathrm{Q}_{\mathrm{g}}\right)$ injected by inverter to the grid are given by Eqs. (13) and (14) respectively.

$P_{g}=\frac{E V}{Z_{g}} \sin \delta(W)$

$Q_{g}=\frac{E V}{Z_{g}} \cos \delta-\frac{V^{2}}{Z_{g}}(V A R)$

where $\mathrm{E}$ and $\mathrm{V}$ are inverter and grid RMS voltages.

$\mathrm{Z}_{\mathrm{g}}$ is grid impedance.

$\delta$ is angle between $\mathrm{E}$ and $\mathrm{V}$ (in radians). $\delta$ is positive if $\mathrm{E}$ leads $\mathrm{V}$ and $\delta$ is considered negative if $\mathrm{E}$ lags $\mathrm{V}$.

In order to operate the inverter in generating region, $\mathrm{P}>0$ and $\delta$ must be positive, i.e., E should lead $\mathrm{V}$ by $+\delta(\mathrm{rad})$. With grid voltage as reference, the grid current, $\mathrm{I}_{\mathrm{g}}$ can be written as

$I_{g} \angle \theta=\frac{E \angle \delta-V \angle 0}{Z_{g} \angle \theta^{\prime}}(A)$

where $\theta$ is phase angle between $\mathrm{V}$ and $\mathrm{I}_{\mathrm{g}}$.

The necessary real power to be injected into the grid is given by the power tracked from PV array (as discussed in previous sections) at a particular insolation and cell temperature. Thus a dependent PQ control strategy is implemented by estimating modulation index and phase angle of the inverter modulating signal. The mathematical relationship between modulation index and inverter voltage is given in the Eq. (16).

$m=\frac{\sqrt{2} E}{V_{D C}}$

The reference phase angle $\left(\delta_{\text {ref }}\right)$ and modulation index $\left(\mathrm{m}_{\text {ref }}\right)$ are determined using Eqs. (17) and (18) respectively.

$\phi_{\text {ref }}=\delta_{r e f}=\left(\frac{P}{Q+\frac{V^{2}}{Z_{g}}}\right) \quad(r a d)$

$m_{r e f}=\frac{\sqrt{2} P Z_{g}}{V_{D C} \times V \sin \sin \delta}$

where $\mathrm{V}_{\mathrm{DC}}$ is input voltage of the single phase PV inverter.

$\mathrm{P}_{\mathrm{g}_{-} \text {ref }}$ and $\mathrm{Q}_{\mathrm{g}_{-} \text {ref }}$ are reference real and reactive powers respectively.

Based on the above Eqs. (13) to (18), a PQ control algorithm is written in m-code format and simulated in MATLAB function block set. 


\section{Results and Discussion}

This section focuses on the comparison of P\&O method with proposed PQ control strategy developed to inject $\mathrm{P}_{\max }$ from PV panel into the grid. The parameters such as settling time and rising time are used for comparison among various methodologies.

\subsection{Conventional Method}

A P\&O for MPPT from PV array mentioned in above sections considered for comparison. The PV voltage, current and power responses for variation in insolation and temperature are reproduced as given in this section and these are shown in Fig. 21. It is observed in the figure that the time taken to track peak power from PV array is about $0.58 \mathrm{~s}$.

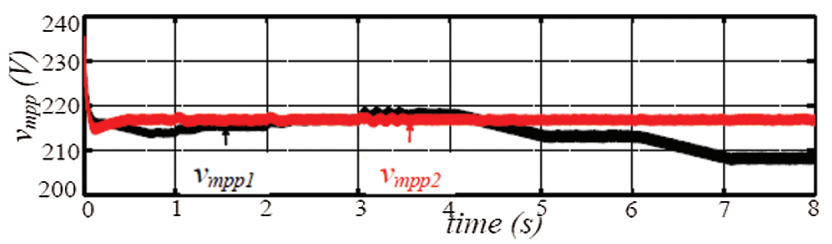

(a)

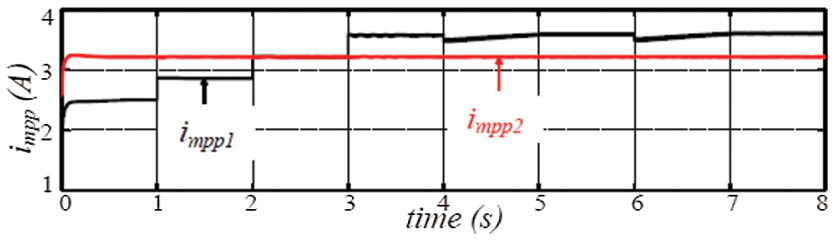

(b)

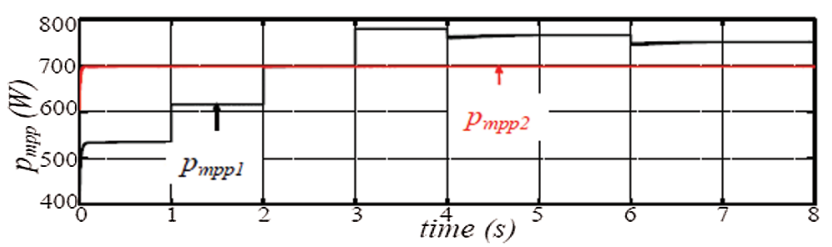

(c)

Figure 21: Transient waveforms of (a) PV voltage (b) PV current (c) PV power

\subsection{Performance with Proposed P-Q Control Strategy}

The proposed PQ control technique is implemented and the steady state inverter voltage, grid voltage and current waveforms for a period of 3 cycles are obtained at STC as shown in Fig. 22.

To study the transient voltage response of the grid connected single phase PV inverter system, the typical variations of solar insolation and temperature are considered as already shown in Fig. 20. The panel power and voltage waveforms are shown in Fig. 23. The inverter voltage and grid current and voltage waveforms are captured and are shown in Figs. 24 and 25 respectively. 
IASC, 2022, vol.33, no.2

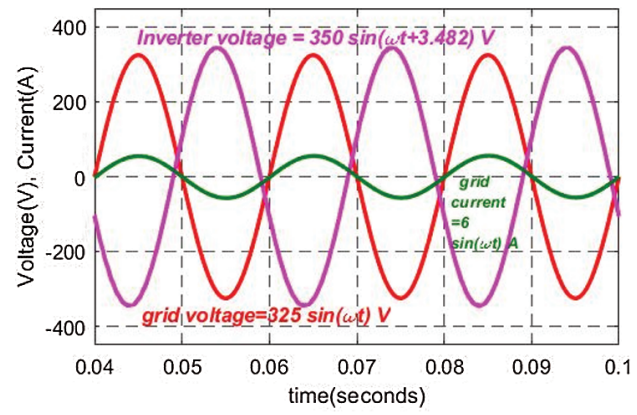

Figure 22: Steady state grid voltage, grid current and inverter voltage waveforms at STC

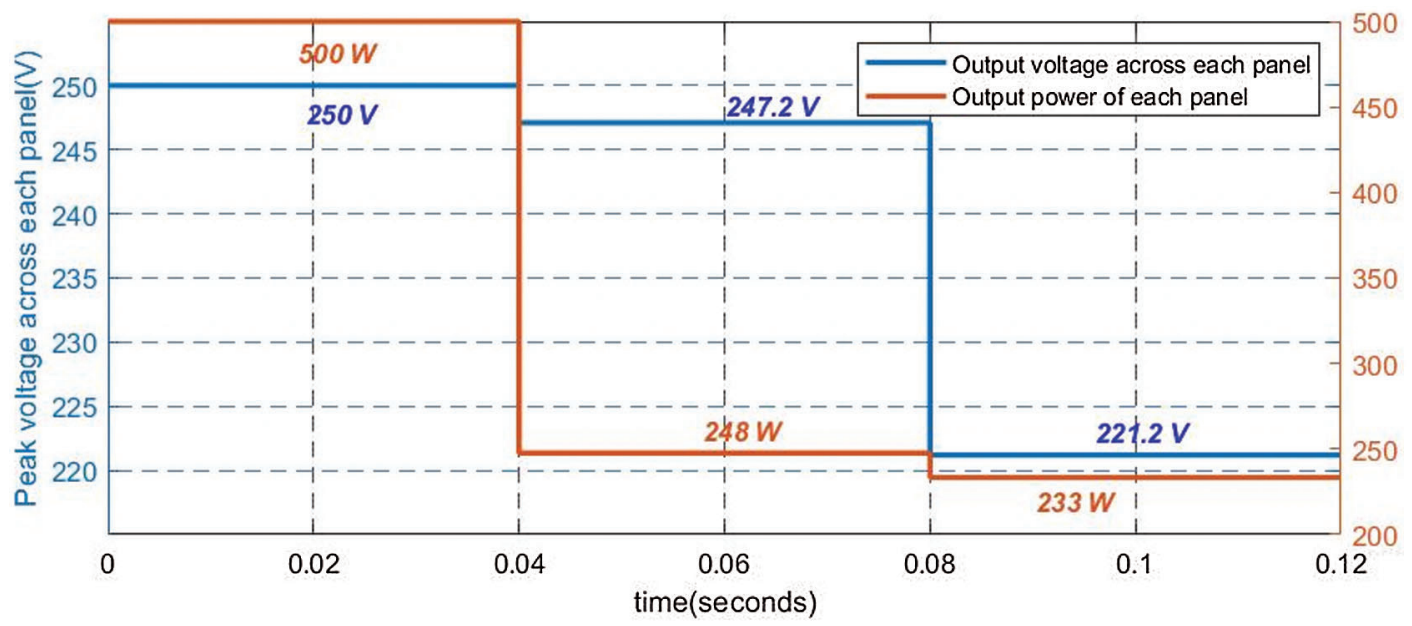

Figure 23: Panel peak power and peak voltage waveform

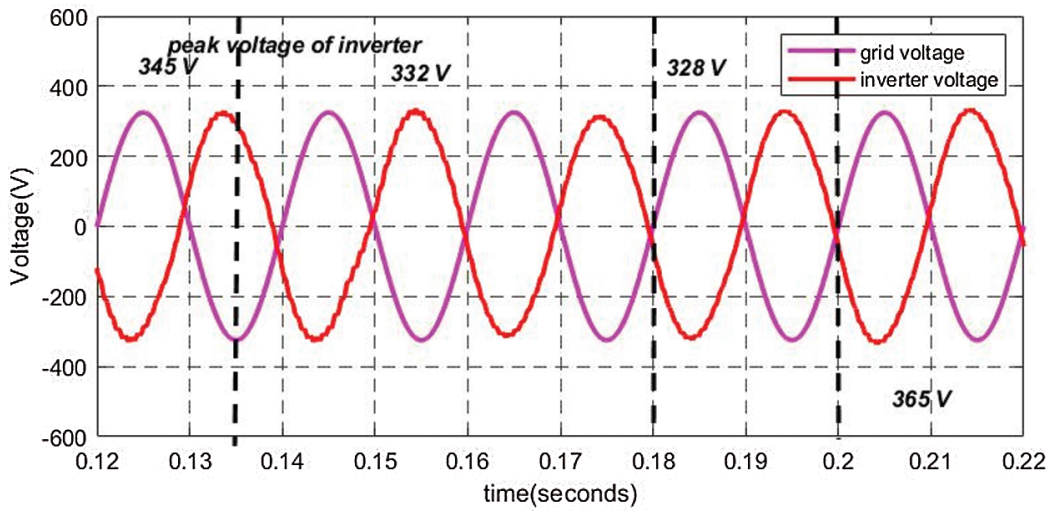

Figure 24: Inverter voltage and grid voltage waveform 


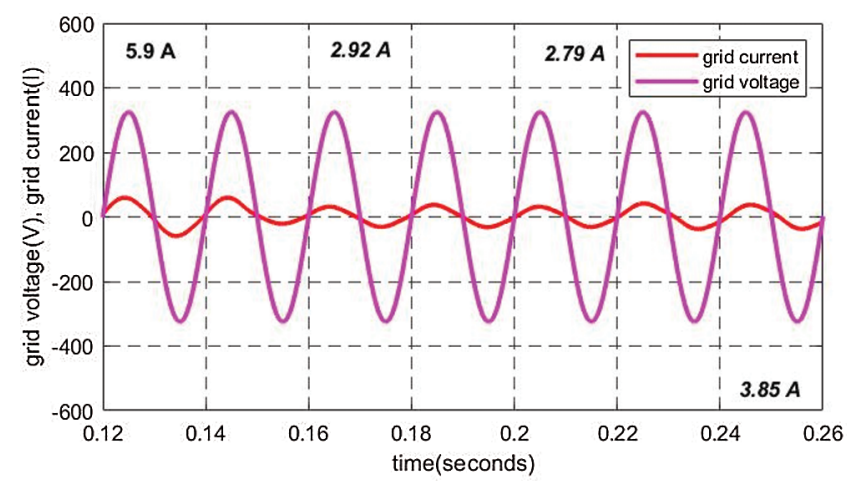

Figure 25: Grid current and grid voltage waveform

From the Fig. 23, it is observed that the peak power changes from 500 to $248 \mathrm{~W}$ whenever there is a change in insolation from 1000 to $500 \mathrm{~W} / \mathrm{m}^{2}$ at $40 \mathrm{~ms}$ similarly the peak power point voltage changes from 250 to $247.2 \mathrm{~V}$. For step change in temperature from $25^{\circ} \mathrm{C}$ to $40^{\circ} \mathrm{C}$ at $80 \mathrm{~ms}$, the peak power of each panel changes from 248 to $233 \mathrm{~W}$. Similarly the peak power point voltage changes from 247.2 to $221.2 \mathrm{~V}$.

From Fig. 22, it is observed that the output voltage waveform reaches steady state within a period of $10 \mathrm{~ms}$ whenever there is a step change in insolation or temperature. The efficiency of grid integrated PV inverter system for different insolation conditions is plotted as shown in Fig. 26. The efficiency is defined as the ratio of grid input power to PV output power.

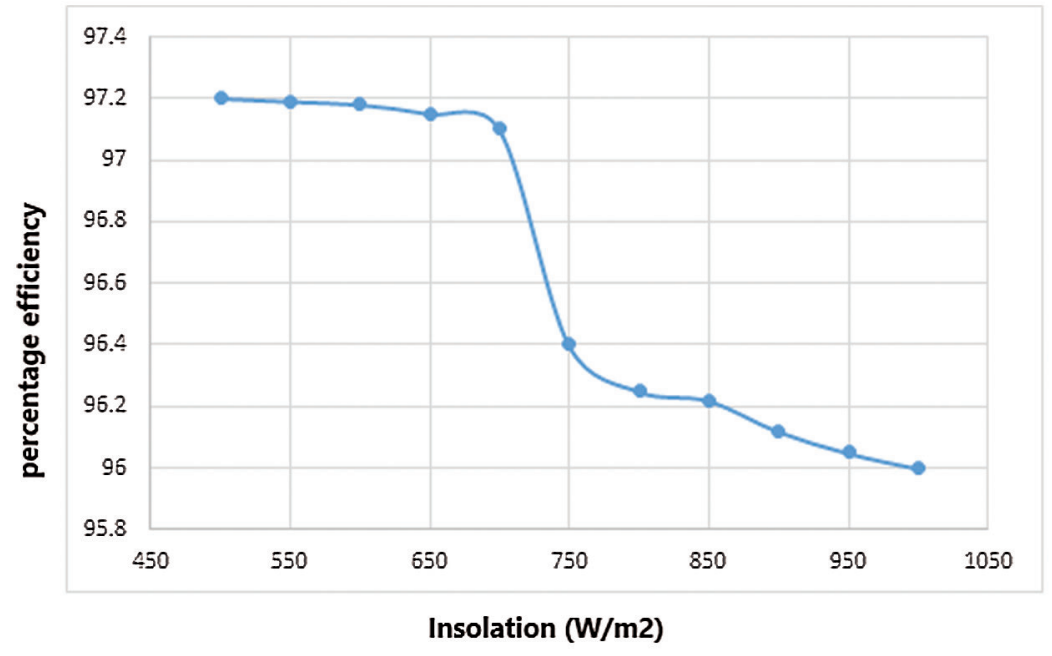

Figure 26: Inverter efficiency for different insolation

The parameters such as settling time and rise time are compared for different technologies are shown in Tab. 3.

It is clear from the table that the settling time taken by the conventional method is large when compared with that of the time taken by proposed control strategy. The rising time is at a minimal microseconds in comparision with other strategy. It is anticipated that the employed method can track the global arrays 
when evaluating the power yield from the arrays. The estimated power yield from each array is calculated by multiplying the total power retrieved from the two arrays by the stated or estimated respective methods. Fig. 27 shows the estimated power yields from the proposed design, P\&O, and GA INC for the aforementioned parameters.

Table 3: Comparison of response parameters

\begin{tabular}{llll}
\hline & P\&O & GA-INC & Proposed \\
\hline Settling time & $0.598 \mathrm{~s}$ & $0.432 \mathrm{~s}$ & $10 \mathrm{~ms}$ \\
Rising time & $0.103 \mathrm{~s}$ & $0.124 \mathrm{~s}$ & $1.2 \mathrm{~ms}$ \\
\hline
\end{tabular}

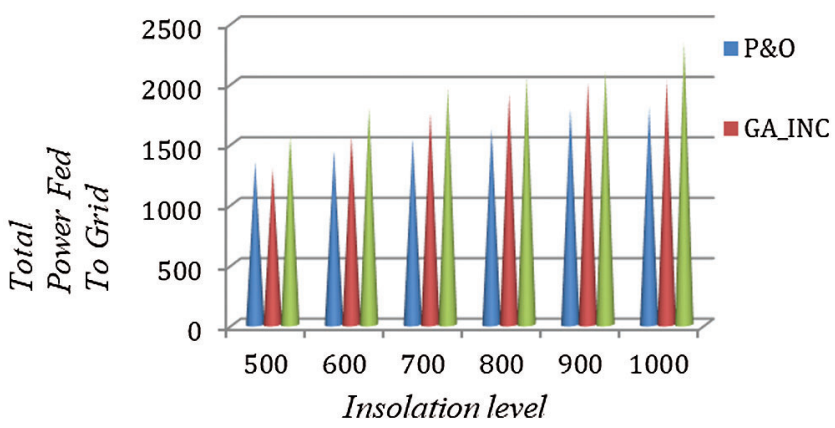

Figure 27: Graphical representation of input power for the grid under various conditions

\section{Conclusion}

A $1 \mathrm{kWp}$ PV array fed single phase grid connected inverter system is designed, modeled and simulated for performance study. Analytical models for PV panel and 1-phase inverter were developed. The performance of this model is validated by comparing its results with those obtained from Simulink model. The transient response of the system has been studied by varying insolation and temperature. The proposed PQ control strategy is able to inject the maximum extracted power from PV panel effectively into the grid. Its performance is compared with the conventional methods during transient and steady state periods. It is finally concluded that the settling time was effectively reduced to $10 \mathrm{~ms}$ with minimum oscillations in the output voltage waveforms and the proposed methodology results $97.2 \%$ efficiency.

Acknowledgement: The authors with a deep sense of gratitude would thank the supervisor for his guidance and constant support rendered during this research.

Funding Statement: The authors received no specific funding for this study.

Conflicts of Interest: The authors declare that they have no conflicts of interest to report regarding the present study.

\section{References}

[1] S. Dutta, D. Debnath and K. Chatterjee, "A Grid-connected single-phase transformer less inverter controlling two solar PV arrays operating under different atmospheric conditions," IEEE Transactions on Industrial Electronics, vol. 65, no. 1, pp. 374-385, 2017. 
[2] M. G. Villalva, J. R. Gazoli and E. R. Filho, "Comprehensive approach to modeling and simulation of photovoltaic arrays," IEEE Transactions on Power Electronics, vol. 24, no. 5, pp. 1198-1208, 2009.

[3] Y. Zhang, S. Lyden, B. L. Barra and M. Haque, "A genetic algorithm approach to parameter estimation for PV modules," in Proc. Power and Energy Society General Meeting, IEEE, Boston, MA, USA, pp. 1-5, 2016.

[4] M. Alqarni and M. K. Darwish, "Maximum power point tracking for photovoltaic system: modified perturb and observe algorithm," in Proc. Universities Power Engineering Conf., IEEE, London, UK, pp. 1-4, 2012.

[5] A. Elbaset, H. Ali and A. E. Sattar, "A modified perturb and observe algorithm for maximum power point tracking of photovoltaic system using buck-boost converter," Journal of Engineering Sciences, vol. 43, no. 3, pp. 344-362, 2015.

[6] R. I. Putri, S. Wibowo and M. Rifa, "Maximum power point tracking for photovoltaic using incremental conductance method," Energy Procedia, vol. 68, pp. 22-30, 2015.

[7] P. U. Mankar and R. M. Moharil, "Comparative analysis of the perturb and observe and incremental conductance MPPT methods," International Journal of Research in Engineering and Applied Sciences, vol. 2, no. 2, pp. 6066, 2014.

[8] A. M. Zaki, S. I. Amer and M. Mostafa, "Maximum power point tracking for PV system using advanced neural networks technique," International Journal of Emerging Technology and Advanced Engineering, vol. 2, no. 12, pp. 58-63, 2012.

[9] S. Messalti, "A new neural networks MPPT controller for PV systems," in Proc. Int. Renewable Energy Congress, IEEE, Sousse, Tunisia, pp. 1-6, 2015.

[10] A. E. Khateb, N. A. Rahim and J. Selvaraj, "Optimized PID controller for both single phase inverter and MPPT SEPIC DC/DC converter of PV module," in Proc. Int. Electrical Machines and Drives Conf., IEEE, Niagara Falls, ON, Canada, pp. 1036-1041, 2011.

[11] R. Blange, C. Mahanta and A. K. Gogoi, "MPPT of solar photovoltaic cell using perturb and observe and fuzzy logic controller algorithm for buck-boost DC-DC converter," in Proc. Int. Conf. on Energy, Power and Environment, IEEE, Shillong, India, pp. 1-5, 2015.

[12] T. N. Nguyen and A. Luo, "Multifunction converter based on lyapunov function used in a photovoltaic system," Turkish Journal of Electrical Engineering \& Computer Sciences, vol. 22, no. 4, pp. 893-908, 2014.

[13] U. Yilmaz, A. Kircay and S. Borekci, "PV system fuzzy logic MPPT method and PI control as a charge controller," Renewable and Sustainable Energy Reviews, vol. 81, pp. 994-1001, 2018.

[14] G. Prathiba, M. Santhi and A. Ahilan, "Design and implementation of reliable flash ADC for microwave applications," Microelectronics Reliability, vol. 88, pp. 91-97, 2018.

[15] K. Kalaiselvi and A. Kumar, "Effect of variations in the population size and generations of genetic algorithms in cryptography-an empirical study," Indian Journal of Science and Technology, vol. 10, no. 19, pp. 1-6, 2017.

[16] A. Appathurai and P. Deepa, "Design for reliablity: A novel counter matrix code for FPGA based quality applications," in Proc. Asia Symp. on Quality Electronic Design, IEEE, Kula Lumpur, Malaysia, pp. 56-61, 2015. 